ISSN 1678-3921

Journal homepage: www.embrapa.br/pab

For manuscript submission and journal contents, access: www.scielo.br/pab
Cassandra Meireles Terres-Ribeiro(1凶) (iD, André Marcelo Knak(2) (iD,

Rosana Aparecida da Silva Buzanello(3) (DD, Denise Pastore de Lima ${ }^{(3)}$ (D),

Roberto Montanhini Neto(4) (iD) and

Ricardo Pereira Ribeiro ${ }^{(1)}$ (iD

(1) Universidade Estadual de Maringá, Avenida Colombo, no 5.790, Bloco J-45, Sala 137 , CEP 87020-900 Maringá, PR, Brazil. E-mail: cassandrameirelest@yahoo.com.br, rpribeiro@uem.br

(2) Faculdades da Indústria - Senai Toledo, Rua Júlio de Castilhos, № 3.465, CEP 85904-175 Toledo, PR, Brazil.

E-mail: andre_m_knak@hormail.com

(3) Universidade Tecnológica Federal do Paraná, Avenida Brasil, № 4.232. Independência, CEP 85884-000 Medianeira, $\mathrm{PR}$, Brazil.

E-mail: rosanabuzanello@gmail.com, denise@utfpr.edu.br

(4) RMN Consultoria Veterinária Ltda., Rua Dom Pedro II, no 2665, CEP 85902-010 Toledo, PR, Brazil.

E-mail: roberto.m.neto@hotmail.com

$\bowtie$ Corresponding author

Received

October 01, 2019

Accepted

September 09, 2020

How to cite

TERRES-RIBEIRO, C.M.; KNAK, A.M.; BUZANELLO, R.A. da S.; LIMA, D.P. de; MONTANHINI NETO, R.; RIBEIRO, R.P. Protein hydrolysate of mechanically separated meat from Nile tilapia. Pesquisa Agropecuária Brasileira, v.55, e01652, 2020. DOI: https://doi. org/10.1590/S1678-3921. pab2020.v55.01652.

\section{Protein hydrolysate of mechanically separated meat from Nile tilapia}

\begin{abstract}
The objective of this work was to enzymatically obtain hydrolysate tilapia protein powder by two drying methods, and to perform a physicochemical characterization of the final products, as well as to evaluate their thermal stability. Proximal composition, aminogram, fatty acid profile, $\mathrm{pH}$, color, water activity, and microbiological analyses were performed. Crude protein was the prominent component, with $87 \%$ in the spray-dried powder and $89 \%$ in the lyophilized powder, showing no statistical difference. The samples showed no bacterial growth, which may be associated with the low water activity in the products. Dry samples had b* positive, and the freeze-dried ones were more yellowish than the spray-dried ones. Both drying methods promoted similar luminosity near the white color. In the thermal analysis, samples showed $26 \%$ mass loss at $200^{\circ} \mathrm{C}$, and degradation started at $290^{\circ} \mathrm{C}$. Enzymatic hydrolysis is efficient, and the hydrolysate tilapia protein powder contains all essential amino acids. The hydrolysate shows similar protein content for both spray-dried and freeze-dried samples, and the final products are stable at high temperatures.
\end{abstract}

Index terms: Oreochromis niloticus, fish by-product, hydrolyzation, protein supplement.

\section{Hidrolisado proteico de carne mecanicamente separada de tilápia-do-nilo}

Resumo - O objetivo deste trabalho foi obter, por via enzimática, um hidrolisado proteico de tilápia em pó, por dois métodos de secagem, e realizar uma caracterização físico-química dos produtos finais, bem como avaliar sua estabilidade térmica. Foram realizadas análises de composição proximal, aminograma, perfil de ácidos graxos, $\mathrm{pH}$, cor, atividade da água e análises microbiológicas. A proteína bruta foi o componente proeminente, com $87 \%$ no pó obtido por secagem por aspersão e $89 \%$ no pó liofilizado, e não apresentou diferença estatística. As amostras não apresentaram crescimento bacteriano, o que pode estar associado à baixa atividade de água dos produtos. As amostras secas tiveram $b^{*}$ positivo, e as amostras secas por liofilização mostraram-se mais amareladas do que as obtidas por aspersão. A secagem em ambos os métodos promoveu luminosidades semelhantes, próximas à cor branca. $\mathrm{Na}$ análise térmica, as amostras apresentaram perda de massa de $26 \%$ a $200^{\circ} \mathrm{C}$, e a degradação foi observada a temperaturas a partir de $290^{\circ} \mathrm{C}$. A hidrólise enzimática é eficiente, e os hidrolisados proteicos de tilápia em pó contém todos os aminoácidos essenciais. $\mathrm{O}$ hidrolisado apresenta teor de proteína semelhante em amostras secas por aspersão e liofilizadas, e os produtos finais são estáveis em altas temperaturas.

Termos para indexação: Oreochromis niloticus, subproduto de pescado, hidrólise, suplemento proteico. 


\section{Introduction}

In 2019, Nile tilapia (Oreochromis niloticus L.) was the major species farmed in Brazil, accounting for $57 \%$ of the Brazilian production, with 758,006 metric tons produced in that year, which means $7.96 \%$ increase in comparison to the production of the previous year, according to the Brazilian Fish Farming Association (Peixe BR, 2020). The Paraná state, in Southern Brazil, was the largest producer, with a production close to 146,000 metric tons in 2019. The western mesoregion of this state led the production of tilapia with about $70 \%$ of the state production (Peixe BR, 2018). According to OECD-FAO... (2018), the world production of fish and aquaculture is estimated to almost double by 2026, with Brazilian production in a leading position to reach this potential (Plano de Desenvolvimento..., 2015; Peixe BR, 2018).

The development of fish hydrolysate started in the 1940s in Canada, and fish hydrolysate is used to modify food functional properties as a source of small peptides and amino acids, or as a supplement in biscuits, hamburgers, and nuggets, among other food, and it is largely used in animal feed as a protein source (Gonçalves, 2011). The product can be obtained using three main methods: alkaline, acidic, or enzymatic hydrolysis; the last one is used with proteolytic enzymes to make protein soluble (Silva et al., 2014). With the use of enzymes, the industry can have a better control over the final product and its characteristics, such as the type of used enzymes that are responsible for determining the size of peptide residues (Bhat et al., 2015).

Nile tilapia is the main aquaculture species produced in Brazil, and its filleting yield is quite low (about 33\%) (Silva et al., 2014), but it generates a large amount of slaughter waste. Hence, a better industrial use of the wasted protein content will allow a higher performance of the slaughtered animals.

The objective of this work was to enzymatically obtain hydrolysate tilapia protein powder by two drying methods, and to perform a physicochemical characterization of the final products, as well as to evaluate their thermal stability.

\section{Materials and Methods}

The experiment was carried out at the Serviço Nacional de Aprendizagem Industrial (Senai), in the municipality of Toledo, and at the Universidade
Tecnológica Federal do Paraná, in the municipality of Medianeira, both in the western Paraná state, Brazil. Filleting residues and mechanically separated meat (MSM) were obtained in a tilapia slaughterhouse registered in the federal inspection service, located in the same region.

Fifty tilapia aged 180 days in average and with 1,050 $\mathrm{g}$ weight were previously desensitized and bled after being eviscerated and decapitated. After these steps, the fillets were removed, and the carcasses were used to produce MSM through the deboner equipment Fish Meat Deboning 600 (BM Machines, Branco Máquinas Ltda., Blumenau, SC, Brazil); then, the MSM was packed in polyethylene bags and subjected to $-18^{\circ} \mathrm{C}$ freezing.

MSM was previously washed with distilled water at $45^{\circ} \mathrm{C}$ and pressed to withdraw the excess liquid. This procedure was repeated four times to remove all residual blood from the slaughter process, as well as to remove the fat excess present in the raw material (Furlan \& Oetterer, 2002). The hydrolysate was obtained enzymatically, using a standard esterase (Alcalase, Novozymes Co., Bagsværd, Denmark). The process consisted of mixing the MSM with water at 1:1 ratio, followed by adding $1 \%$ of the enzyme (Furlan \& Oetterer, 2002). The hydrolysis took $120 \mathrm{~min}$, and the enzyme inactivation occurred at $90^{\circ} \mathrm{C}$ for $10 \mathrm{~min}$, followed by centrifugation at $3,000 \mathrm{rpm}$ for $10 \mathrm{~min}$, using a benchtop centrifuge Excelsa II 206 BL (Fanem, SP, Brazil). For the further use of this hydrolyzed powder in foods, the hydrolysis was performed without the $\mathrm{pH}$ correction.

The hydrolysis evolution was also evaluated by using the enzyme Alcalase at $0.5 \%$ (1:200), and hydrolysis times of 10, 20, 30, 60, and $120 \mathrm{~min}$.

After the enzymatic process, the obtained supernatant material containing the hydrolyzed protein was subjected to two different drying processes: by using a spray dryer LM 1.0 (Labmaq do Brasil Ltda., Ribeirão Preto, SP, Brazil), with inlet air at $120^{\circ} \mathrm{C}$, feed rate of $0.5 \mathrm{~L} \mathrm{~h}^{-1}$, and an inlet-air flow at $3.5 \mathrm{~m}^{3} \mathrm{~min}^{-1}$; and lyophilization, by which the frozen material (at $-32^{\circ} \mathrm{C}$ ) was introduced into a vacuum chamber FreeZone Freeze Dryer System (Labconco, Kansas City, MO, USA), with absolute pressure of less than $50 \mathrm{~Pa}$, exchanging heat at $40^{\circ} \mathrm{C}$ for 36 hours.

Moisture, ash, and crude protein contents were determined according to the official methods 923.03 , 
925.45b, 960.52 described by the AOAC (Helrich, 1990).

The total lipids were extracted according to the method described by Bligh \& Dyer (1959), with some modifications. Tilapia MSM samples were ground in a common food mixer Multiprocessador All in One 800W (Philco do Brasil, Manaus, AM, Brazil). The aliquot of $15 \mathrm{~g}$ of grounded MSM and the hydrolysates were collected for extraction and, after moisture correction to $80 \%, 30 \mathrm{~mL}$ of methanol were added to each sample and homogenized with a glass rod, followed by the addition of $15 \mathrm{~mL}$ chloroform, and magnetic stirring for $5 \mathrm{~min}$. After this, $15 \mathrm{~mL}$ chloroform were added, while stirring continued for $2 \mathrm{~min}$; then, $15 \mathrm{~mL}$ distilled water were added, and the magnetic stirring continued for another $5 \mathrm{~min}$. The homogenate was filtered in a Büchner funnel with filter paper under vacuum, and the residue was rinsed with $20 \mathrm{~mL}$ chloroform and filtered. The filtrate was transferred to a separation funnel and added to $1 / 5$ of the filtered volume with a saturated $\mathrm{NaCl}$ solution equivalent. After the separation of the phases, the bottom phase containing chloroform and grease was collected in a flat-bottomed volumetric flask and taken to a rotary evaporator model 801 (Fisatom Equipamentos Científicos Ldta., São Paulo, SP, Brazil) at $33-34^{\circ} \mathrm{C}$ to remove the solvent. These analyses were done in triplicate.

The high-performance liquid chromatography 1290 Infinity UHPLC (Agilent Technologies, Santa Clara, CA, USA) and the enzymatic method were used to determine the amino acid profile (White et al., 1986). The hydrolysis and transesterification of fatty acids were performed according to the method 5509 (ISO, 2000).

The fatty acid methyl esters were quantified using a gas chromatograph with a flame ionization detector Clarus 680 GC (PerkinElmer Inc., Waltham, MA, USA) and a fused silica capillary column (100 m x $0.25 \mathrm{~mm}$ ) with $0.25 \mu \mathrm{m}$ cyanopropyl polysiloxane J\&W Select FAME GC Column CP7420 (Agilent Technologies, Santa Clara, USA) (Silva-Buzanello et al. 2018). The column temperature ramp was programmed at $80^{\circ} \mathrm{C}$ for $1 \mathrm{~min}$; ramped at $20^{\circ} \mathrm{C} \mathrm{m^{-1 }}$ to $160^{\circ} \mathrm{C}$; then ramped at $1^{\circ} \mathrm{C} \mathrm{min}^{-1}$ to $198^{\circ} \mathrm{C}$; ramped at $5^{\circ} \mathrm{C} \mathrm{min} \mathrm{m}^{-1}$ to $250^{\circ} \mathrm{C}$ and held for $1.6 \mathrm{~min}$. The detector and injector were maintained at $250^{\circ} \mathrm{C}$ and $240^{\circ} \mathrm{C}$, respectively, using a $1 / 150$ split. The gas flow was $1.1 \mathrm{~mL} \mathrm{~min}^{-1}$ for the entrainment gas $(\mathrm{He})$, and 40 and $400 \mathrm{~mL} \mathrm{~min}^{-1}$ for the flue gases $\mathrm{H}_{2}$ and synthetic air, respectively. The identification of fatty acids was based on fatty acid methyl ester standards (FAME, Sigma-Aldrich, Darmstadt, Germany). The area of the peaks was determined by an integrator coupled to the gas chromatograph. The results were expressed as relative percentages of the identified fatty acids.

The Fourier-transform infrared spectroscopy (FTIR) analyses were conducted using a FT spectrophotometer Frontier Spectrum 100 (PerkinElmer Inc., Waltham, MA, USA). The attenuated total reflectance (ATR) mode was used at the wave range of 4000-600 $\mathrm{cm}^{-1}$, with a resolution of $4 \mathrm{~cm}^{-1}$, in a total of 10 accumulations. The straight baseline passing through the ordinates at 1,600 and 1,675 $\mathrm{cm}^{-1}$ (amide I band) was adjusted to an additional parameter to obtain the best fit. The deconvolution of this wave number range was determined using a Gaussian curve fit.

Considering that all main secondary structural elements constituted a linear sum in the proteins and that the percentage of each one was related to the spectral intensity, the $\beta$-sheet, $\alpha$-helix, and $\beta$-turn portions were determined (Kong \& Yu, 2007).

The thermal analysis, differential scanning calorimetry (DTA), and thermogravimetric (TG) analyses were performed on STA 6000 equipment (PerkinElmer Inc., Waltham, MA, USA). To obtain the DTA and TG curves, $1.0 \mathrm{mg}$ of each sample was conditioned in aluminum crucibles and heated from 50 to $600^{\circ} \mathrm{C}$, at $10^{\circ} \mathrm{C} \mathrm{min}-1$ rate, and under $\mathrm{N}_{2}$ constant flow $\left(20 \mathrm{~mL} \mathrm{~min}^{-1}\right)$. The equipment was previously calibrated using an Indian reference standard (Diéguez et al., 2010). The thermal behavior was evaluated based on the attained DTA and TG curves.

A brand colorimeter CR 400 (Konica Minolta, Chiyoda, Japan) with illuminant D65 and $10^{\circ}$ viewing angle was used for color analysis. The color measurements were carried out at three different superficial points of the hydrolysates and of the raw material, corresponding to the central and the lateral parts of the samples, and the values of $\mathrm{L}^{*}$ (brightness), $\mathrm{a}^{*}$ (red to green component), and $\mathrm{b}^{*}$ (yellow-blue component) were expressed according to the color system of the CIE (2007); the analysis was performed in five replicates.

The $\mathrm{pH}$ measurements were carried out at room temperature, using a precision $\mathrm{pH}$ meter $\mathrm{pH} 21$ (Hanna 
Instruments, Póvoa de Varzim, Portugal), and via direct calibration in the hydrolysates and in products. The sample was homogenized with $40 \mathrm{~mL}$ distilled water.

Water activity $\left(\mathrm{A}_{\mathrm{w}}\right)$ was evaluated at $25^{\circ} \mathrm{C}$ in the $\mathrm{A}_{\mathrm{w}}$ determinant Aqualab 4TE (Decagon, Pulmann, WA, USA).

The hydrolysate powder was evaluated microbiologically for coagulase-positive Staphylococcus (ISO, 1999; Latimer Jr., 2019), Salmonella sp. (Latimer Jr., 2019), and coliform counts at $45^{\circ} \mathrm{C}$ (Latimer Jr., 2019), according to Brazilian regulation (Anvisa, 2001). In addition to these mentioned analyses, in order to comply with the international legislation (Huss, 1994), the hydrolysates were also subjected to the evaluation of contamination by Escherichia coli (Latimer Jr., 2019) and Staphylococcus aureus (Latimer Jr., 2019). All analyses were performed 48 hours after freezing.

The analysis of variance and the Tukey's test, at $5 \%$ probability, were used to evaluate the data obtained of proximal composition, color, $\mathrm{pH}$, and $\mathrm{Aw}$ measurements.

\section{Results and Discussion}

The hydrolysis process produced $38.96 \%$ gain of protein over raw material (Table 1). The increase of the protein content in the washed and pressed sample is due to the partial removal of the lipids, as described by Kristinsson \& Rasco (2000). It can be verified that the hydrolysis was efficient in spray-dried and freeze-dried samples. Protein values were similar to those reported by Silva et al. (2014), who had dried fish hydrolysates that contained $85-90 \%$ protein. Robert et al. (2015) found $80 \%$ protein values in hydrolysates that were obtained using $0.15 \%$ Protamex enzyme and filletin waste. These values were considered satisfactory due to the low humidity of the final product. These results confirm the potential of this product for use as a supplement or nutraceutical for the food industry.

Lipids levels in the dry hydrolysate sample in the present study were higher than those specified by Roslan et al. (2014) as $0.08 \%$, handling red tilapia (Oreochromis niloticus), and $2.5 \%$ Alcalase enzyme (w/w). Silva et al. (2014) showed values between 37 and $44 \%$, using viscera and carcasses of Nile tilapia (Oreochromis niloticus). The results are directly linked to the raw material. The washed sample had $70 \%$ lower lipid content than that of the raw material.

The fatty acids found in higher concentrations were palmitic acid (16:0), oleic acid (18:1, n-9), and linoleic acid (18:2, n-6) (Table 2). Our study corroborates the findings of Rasoarahona et al. (2005) and Navarro et al. (2012), who evaluated also the fatty acid profile of Nile tilapia, and found results regarding the major fatty acids.

An increase of the amino acid contents of the hydrolysates can be verified, except for taurine and phenylalanine (Table 3). The presence and value of the amino acids in both products indicate that the treatments applied do not affect the quality of the final product. Among the 21 amino acids, 19 were investigated and found in the hydrolysates, and the 9 essential amino acids were also present.

Tilapia hydrolysate samples obtained by Robert et al. (2015), using the enzyme Protamex, found $68.2 \%$ of the total amino acids, and $32.5 \%$ of essential amino acids. Our study shows $88.41 \%$ and $90.77 \%$ of the total amino acids and $35.96 \%$ and $36.84 \%$ of the essential amino acids, for freeze-dried and spraydried samples, respectively. Abdul-Hamid et al. (2002) found also glutamic acid as the major amino acid. The predominance of acid or basic amino acids interferes with the final product pH (Damodaran et al., 2007), a fact that explains the $\mathrm{pH}$ of 6.24 for the spray-dried samples that had a predominance of glutamic acid.

Table 1. Proximal composition of mechanically separated meat (MSM) and protein hydrolysates of tilapia (Oreochromis niloticus) dried by lyophilization and spray-drying, including mean and standard deviation ${ }^{(1)}$.

\begin{tabular}{lcrrr}
\hline Analysis & MSM in natura & Washed MSM & Spray-dried hydrolysate & Lyophilized hydrolysate \\
\hline Moisture (\%) & $78.47 \pm 0.18 \mathrm{~b}$ & $80.92 \pm 0.56 \mathrm{a}$ & $1.94 \pm 0.20 \mathrm{~d}$ & $2.94 \pm 0.52 \mathrm{c}$ \\
Ash (\%) & $0.92 \pm 0.87 \mathrm{~b}$ & $0.45 \pm 0.65 \mathrm{c}$ & $2.15 \pm 0.37 \mathrm{a}$ & $2.05 \pm 0.71 \mathrm{a}$ \\
Protein (\%) & $12.26 \pm 0.08 \mathrm{c}$ & $19.98 \pm 0.94 \mathrm{~b}$ & $87.49 \pm 0.16 \mathrm{a}$ & $89.80 \pm 2.76 \mathrm{a}$ \\
Fat (\%) & $4.85 \pm 1.18 \mathrm{a}$ & $1.36 \pm 0.13 \mathrm{~b}$ & $1.18 \pm 0.07 \mathrm{~b}$ & $0.79 \pm 0.47 \mathrm{~b}$ \\
\hline
\end{tabular}

${ }^{(1)}$ ifferent letters in the same row indicate significant differences by Tukey's test, at $5 \%$ probability. 
The protein samples of lyophilized and spray-dried hydrolysates showed similar thermal behavior. Both samples showed a mass loss of $26 \%$ at $200^{\circ} \mathrm{C}$, and the onset of degradation was observed at $290^{\circ} \mathrm{C}$ (Figure 1). These results attest that the protein hydrolysates, regardless of the type of drying, show good thermal stability, and their application may be suggested for the manufacture of products which have to be subjected to heat treatments at temperatures below $290^{\circ} \mathrm{C}$ (such as cakes, sausages, or cheese bread for instance).

As to the FTIR-ATR spectra and the major absorption bands observed in the tilapia hydrolysate samples, as well as the bands corresponding to the amide A,

Table 2. Fatty acids profile detected in samples of mechanically separated meat (MSM) and protein hydrolysates of Nile tilapia (Oreochromis niloticus) dried by lyophilization and spray-drying.

\begin{tabular}{|c|c|c|c|}
\hline \multirow[t]{2}{*}{ Fatty acid } & \multicolumn{3}{|c|}{ Samples (relative $\%$ of fatty acids) } \\
\hline & $\begin{array}{l}\text { MSM in } \\
\text { natura }\end{array}$ & $\begin{array}{l}\text { Lyophilized } \\
\text { hydrolysate }\end{array}$ & $\begin{array}{l}\text { Spray-dried } \\
\text { hydrolysate }\end{array}$ \\
\hline 14:0 (myristic acid) & 3.1 & 0.08 & 3.33 \\
\hline 14:1 (palmitic acid) & 0.2 & 0.15 & 0.12 \\
\hline 15:0 (methyltetradecanoic acid) & 0.3 & nd & 0.28 \\
\hline 16:0 (palmitic acid) & 25.8 & 27.86 & 27.31 \\
\hline 16:1 (palmitoleic acid) & 5.9 & 5.15 & 5.96 \\
\hline 17:0 (heptadecanoic acid) & 0.4 & nd & 0.40 \\
\hline 17:1 (heptadecenoic acid) & 0.4 & nd & 0.33 \\
\hline 18:0 (stearic acid) & 7.4 & 8.88 & 7.56 \\
\hline 18:1n-9c (oleic acid) & 35.4 & 38.22 & 35.73 \\
\hline 18:2n-6c (linoleic acid) & 12.2 & 11.67 & 11.51 \\
\hline $18: 3 n-6(\gamma$-linolenic acid $)$ & 0.8 & 0.52 & 0.73 \\
\hline 20:0 (eicosanoic acid) & 0.3 & 0.29 & 0.34 \\
\hline 18:3n-3 ( $\alpha$-linolenic acid) & 0.8 & 0.58 & 0.75 \\
\hline 20:1n-9 (gadoleic acid) & 2.0 & 1.69 & 2.06 \\
\hline 21:0 (henicosanoic acid) & 0.4 & nd & 0.32 \\
\hline 20:2 (eicosadienoic) & 0.7 & 0.40 & 0.62 \\
\hline 20:3n-6 (dihomo- $\gamma$-linolenic acid) & 0.8 & 0.33 & 0.57 \\
\hline 22:0 (behenic acid) & nd & 0.14 & nd \\
\hline 20:4n-6 (arachidonic acid) & 1.7 & 0.75 & 0.96 \\
\hline 22:6n-3 (docosahexaenoic acid) & 0.9 & 0.44 & 0.47 \\
\hline SFA & 37.9 & 37.25 & 39.53 \\
\hline MUFA & 44.4 & 45.20 & 44.86 \\
\hline PUFA & 17.2 & 14.28 & 14.99 \\
\hline$\sum \mathrm{n}-6$ & 15.5 & 13.27 & 13.77 \\
\hline$\sum n-3$ & 1.7 & 1.02 & 1.22 \\
\hline$n-6: n-3$ ratio & 9.11 & 13.00 & 11.28 \\
\hline
\end{tabular}

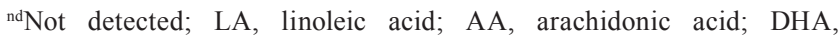
docosahexaenoic acid; SFA, saturated fatty acids; MUFA, monounsaturated fatty acids; PUFA, polyunsaturated fatty acids.
Table 3. Amino acid profile (\%) detected in samples of mechanically separated meat and protein hydrolysates from Nile tilapia (Oreochromis niloticus) dried by lyophilization and spray-drying.

\begin{tabular}{|c|c|c|c|}
\hline Amino acid & $\begin{array}{c}\text { Mechanically } \\
\text { separated meat }\end{array}$ & $\begin{array}{l}\text { Lyophilized } \\
\text { hydrolysate }\end{array}$ & $\begin{array}{l}\text { Spray-dried } \\
\text { hydrolysate }\end{array}$ \\
\hline Aspartic acid & 8.61 & 10.35 & 10.11 \\
\hline Glutamic acid & 10.83 & 14.30 & 16.11 \\
\hline Serine & 3.05 & 3.82 & 3.71 \\
\hline Glycine & 3.97 & 4.94 & 4.73 \\
\hline Histidine* & 1.76 & 1.86 & 1.80 \\
\hline Taurine & 0.87 & nd & nd \\
\hline Arginine & 4.53 & 6.11 & 6.72 \\
\hline Threonine* & 3.37 & 4.25 & 4.04 \\
\hline Alanine & 4.43 & 5.66 & 5.98 \\
\hline Proline & 2.69 & 3.81 & 3.41 \\
\hline Tyrosine & 2.18 & 2.47 & 2.21 \\
\hline Valine* & 3.47 & 4.04 & 3.94 \\
\hline Methionine* & 1.92 & 2.48 & 2.43 \\
\hline Cysteine & 0.70 & 0.99 & 0.95 \\
\hline Isoleucine* & 3.73 & 3.81 & 3.77 \\
\hline Leucine* & 6.10 & 7.11 & 7.54 \\
\hline Phenylalanine* & 2.88 & 2.75 & 2.44 \\
\hline Lysine* & 7.56 & 9.06 & 10.33 \\
\hline Tryptophan* & 0.70 & 0.60 & 0.55 \\
\hline Total AA & 73.35 & 88.41 & 90.77 \\
\hline Total of essential AA & 31.49 & 35.96 & 36.84 \\
\hline
\end{tabular}

*Essential amino acids; AA, amino acids. ${ }^{\text {nd }}$ Not detected.

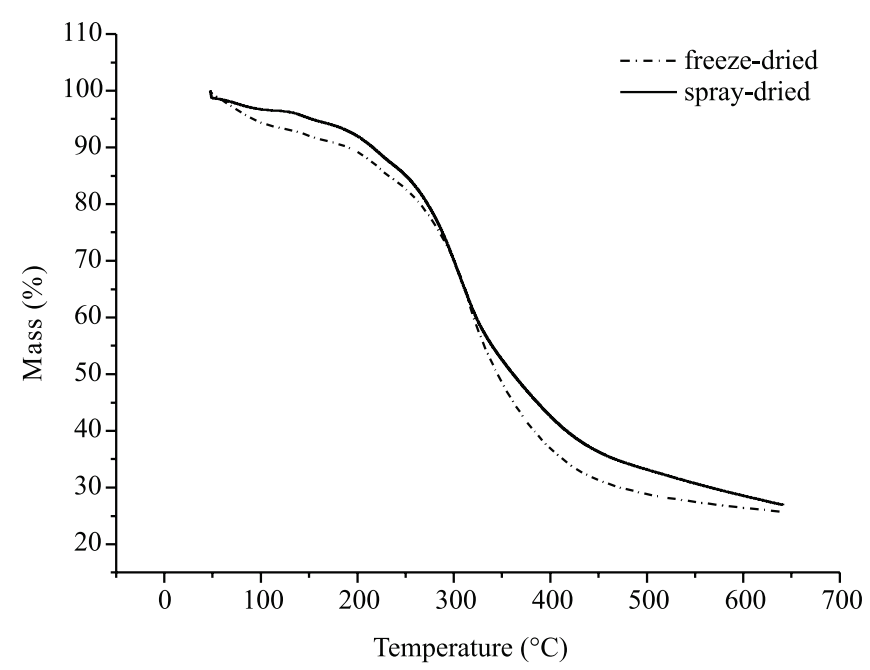

Figure 1. Thermogravimetric (TG) analyses of hydrolyzed protein samples from mechanically separated meat of Nile tilapia (Oreochromis niloticus) dried by lyophilization and spray drying. 
primary amide, and secondary amide linkages (Sow \& Yang, 2015), a difference in the $1,642 \mathrm{~cm}^{-1}$ band, corresponding to the $\mathrm{C}=\mathrm{O}$ linkage of the primary amide, was observed between the samples depending on the type of drying of the hydrolysate (Figure 2).

The differences in secondary structures observed in proteins (Figure 3) are suggested by deconvolution analysis of the amide I band (Kong \& Yu, 2007). Tilapia protein hydrolysate dried by lyophilization showed a greater proportion of $\beta$-sheet structure $(65.14 \%)$ than those dried by a spray dryer $(26.76 \%)$ (Table 4). $\beta$-sheet structures are more hydrophobic and have higher thermal stability than those of the $\alpha$-helix type (Walsh, 2014). However, in dry samples by a spray dryer, there was a higher incidence of aggregate formation and random structures, suggesting the amorphous nature of the protein, differently from that observed by lyophilization, which can be characterized as more organized structures. Secondary structures of the $\alpha$-helix type contain polar and nonpolar amino acids, which characterizes an amphiphilic structure (Damodaran et al., 2007). However, both proteins have

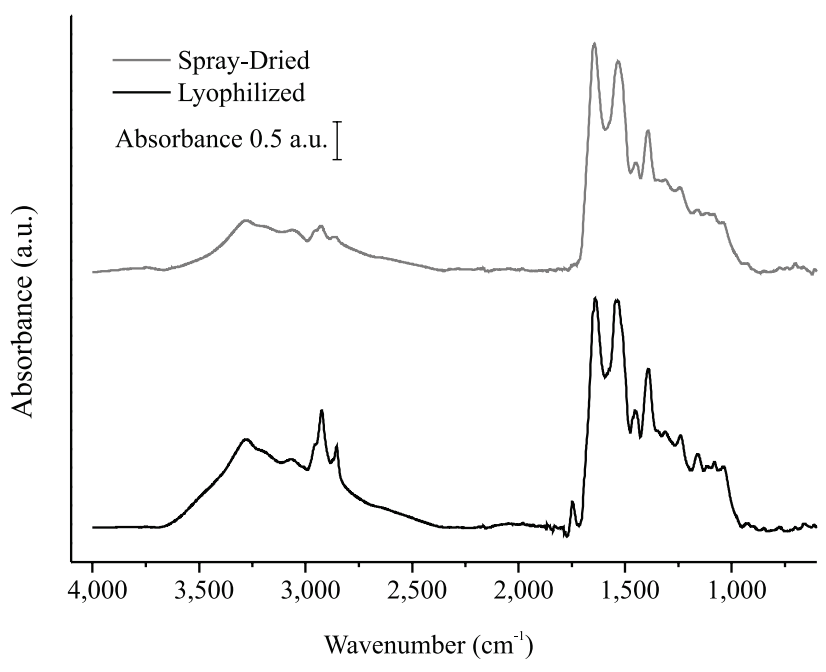

Figure 2. Spectra by Fourier transform infrared spectroscopy, in an attenuated reflectance mode (FTIRATR), for the hydrolyzed samples from mechanically separated meat of Nile tilapia (Oreochromis niloticus) dried by lyophilization and spray-drying. low and similar $\alpha$-helix content, which corroborates the absence of emulsifying ability observed in the proteins obtained in the present study.

The dry samples displayed a coloration closer to white (Table 5), the lyophilized sample being brighter than the spray-dried sample, and $b^{*}$ positive value indicating yellowish shades. This can be explained by the high temperatures used for drying, which are
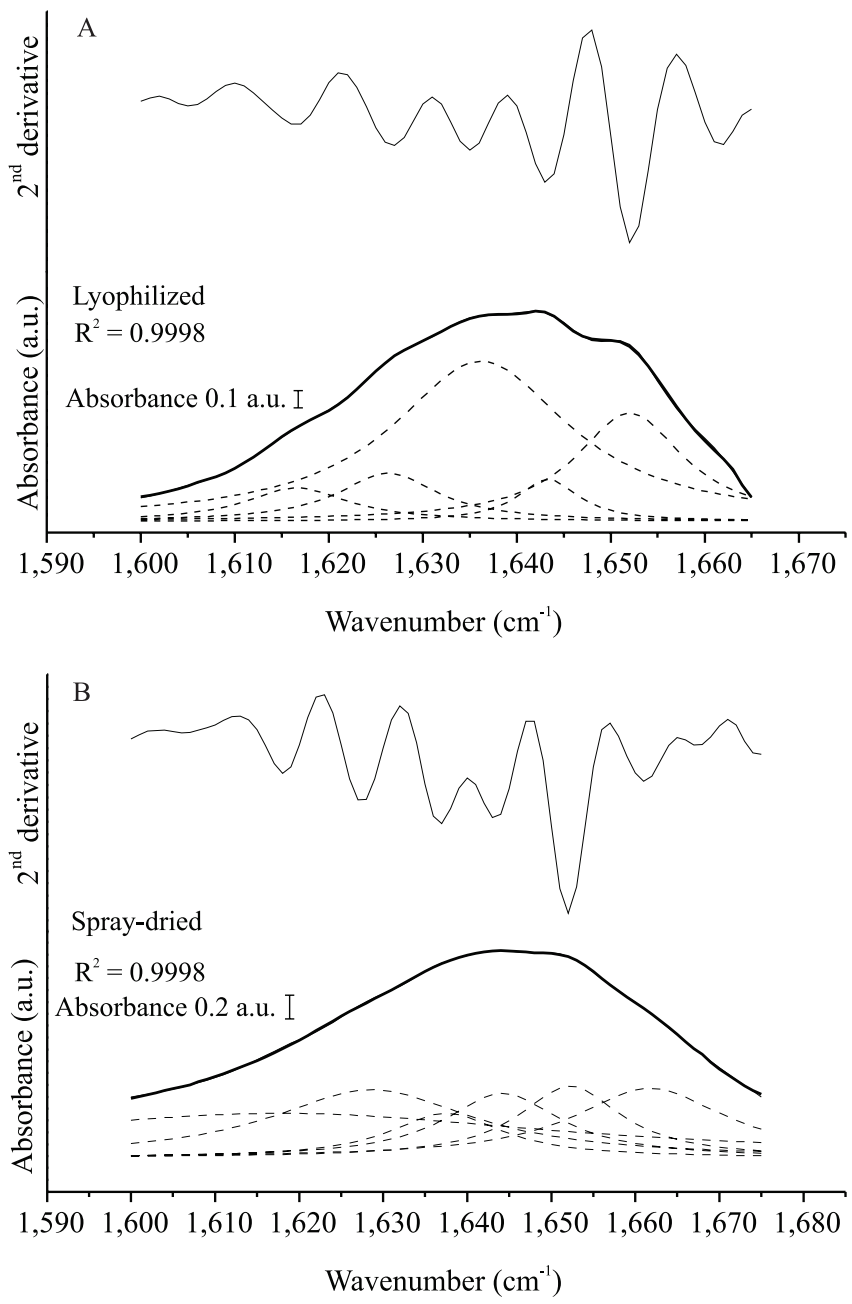

Figure 3. Deconvoluted spectra by Fourier transform infrared spectroscopy, in an attenuated reflectance mode (FTIR-ATR) for hydrolyzed samples from mechanically separated meat of Nile tilapia (Oreochromis niloticus) dried by lyophilization (at the top) and spray-drying (at the bottom). Wavenumber ranges from 1,675 to $1,600 \mathrm{~cm}^{-1}$ corresponding to the amide I band. Thick solid line represents the original FTIR-ATR spectrum; solid line, Gaussian curve-fit; dashed lines, peaks from the deconvolution analysis. 
propitious for the occurrence of the Maillard reaction (Damodaran et al., 2007). However, the MSM showed almost intermediate luminosity and a positive value indicative of the red color coordinate, a fact that is justified, since the analyzed sample had not passed through the washing process and had still residual blood from the slaughter process. The value of $h^{*}$

Table 4. Comparison of protein secondary structures (\%) of hydrolyzed protein samples from mechanically separated meat of tilapia (Oreochromis niloticus) dried by lyophilization and spray-drying, determined by Fourier transform infrared spectroscopy - attenuated reflectance mode (FTIR-ATR) with self-deconvolution.

\begin{tabular}{lcc}
\hline Wavenumber $\left(\mathrm{cm}^{-1}\right)$ & $(\%)$ & Assignment \\
\hline & \multicolumn{2}{c}{ Lyophilized samples } \\
1616 & 6.7 & Aggregated strains \\
1626 & 9.34 & $\beta$-sheet \\
1635 & 55.8 & $\beta$-sheet \\
1643 & 5.0 & Random coil \\
1652 & 23.0 & $\alpha$-helix \\
\hline \multicolumn{3}{c}{ Spray-dried samples } \\
1617 & 36.3 & Aggregated strains \\
1627 & 19.6 & $\beta$-sheet \\
1637 & 7.2 & $\beta$-sheet \\
1643 & 10.8 & Random coil \\
1652 & 10.6 & $\alpha$-helix \\
1661 & 15.3 & $\alpha$-helix \\
\hline
\end{tabular}

Table 5. Mean \pm standard deviation of color evaluation, water activity $\left(\mathrm{A}_{\mathrm{w}}\right)$, and $\mathrm{pH}$ of mechanically separated meat (MSM) and enzymatically obtained protein hydrolysates of Nile tilapia (Oreochromis niloticus) ${ }^{(1)}$.

\begin{tabular}{lrrr}
\hline Analyses & $\begin{array}{c}\text { Mechanically } \\
\text { separated meat }\end{array}$ & $\begin{array}{l}\text { Lyophilized } \\
\text { hydrolysate }\end{array}$ & $\begin{array}{r}\text { Spray-dried } \\
\text { hydrolysate }\end{array}$ \\
\hline Color $^{(2)}$ & & & \\
$\mathrm{L}^{*}$ & $60.91 \pm 2.64$ & $89.62 \pm 1.74 \mathrm{a}$ & $82.86 \pm 2.48 \mathrm{a}$ \\
$\mathrm{a}^{*}$ & $3.45 \pm 1.42$ & $-6.11 \pm 0.16 \mathrm{~b}$ & $-4.86 \pm 0.26 \mathrm{a}$ \\
$\mathrm{b}^{*}$ & $16.01 \pm 0.94$ & $13.27 \pm 0.39 \mathrm{a}$ & $8.62 \pm 0.19 \mathrm{~b}$ \\
$\mathrm{~h}^{*}$ & $77.01 \pm 2.06$ & $114.54 \pm 0.20 \mathrm{a}$ & $119.33 \pm 0.28 \mathrm{a}$ \\
\hline $\mathrm{A}_{\mathrm{w}}$ & $0.99 \pm 0.01$ & $0.12 \pm 0.01 \mathrm{~b}$ & $0.53 \pm 0.01 \mathrm{a}$ \\
$\mathrm{pH}$ & $6.97 \pm 0.01$ & $6.47 \pm 0.01 \mathrm{a}$ & $6.24 \pm 0.01 \mathrm{~b}$ \\
\hline
\end{tabular}

(1)Means followed by different letters in the same row, indicate significant differences between lyophilized and spray-dried hydrolysates, by the F-test, at $5 \%$ probability. ${ }^{(2)} \mathrm{L}^{*}$, brightness; a*, red to green component (positive values indicate red, and negative values indicate green); $\mathrm{b}^{*}$, yellow to blue component (positive values indicate yellow, and negative ones indicate blue); $\mathrm{h}^{*}$, hue, or color tone. $\mathrm{n}=3$. (hue) is a measure of color tone, and according to this characteristic, the dry samples have very close tones, differing from the MSM tonality.

The $A_{w}$ values of the hydrolysates were 0.12 for the lyophilized sample and 0.53 for the spray-dried one, both below the limiting value for the growth of microorganisms, set at 0.6 , according to Rahman \& Labuza (2007). Microbiological analyses did not show bacterial growth. This fact is justified by the low $A_{w}$ (Table 4) and by the low-moisture content found in the products (Table 1). The water bound to macromolecules by physical forces is not free to act as a solvent or to be used in chemical reactions, therefore it is not suitable for the growth of microorganisms (Rahman \& Labuza, 2007), although $\mathrm{pH}$ is conducive to microbial development (Rahman, 2007).

\section{Conclusions}

1. The enzymatic hydrolysis of mechanically separated meat from Nile tilapia (Oreochromis niloticus) is efficient, and the obtained hydrolysate shows similar protein content in both spray-dried and freeze-dried samples.

2. The obtained products are a source of all essential amino acids.

3. Powders obtained are stable at high temperatures, initiating the degradation at $290^{\circ} \mathrm{C}$.

\section{References}

ABDUL-HAMID, A.; BAKAR, J.; BEE, G.H. Nutritional quality of spray dried protein hydrolysate from Black Tilapia (Oreochromis mossambicus). Food Chemistry, v.78, p.69-74, 2002. DOI: https://doi.org/10.1016/S0308-8146(01)00380-6.

ANVISA. Agência Nacional de Vigilância Sanitária. Resolução RDC n ${ }^{\circ} 12$, de 02 de janeiro de 2001. [Regulamento Técnico sobre Padrões Microbiológicos para Alimentos]. Diário Oficial da União, 10 jan. 2001. Seçãol.

BHAT, Z.F.; KUMAR, S.; BHAT, H.F. Bioactive peptides of animal origin: a review. Journal of Food Science and Technology, v.59, p.5377-5392, 2015. DOI: https://doi.org/10.1007/s13197-0151731-5.

BLIGH, E.G.; DYER, W.J. A rapid method of total lipid extraction and purification. Canadian Journal of Biochemistry and Physiology, v.37, p.911-917, 1959. DOI: https://doi.org/10.1139/ o59-099.

CIE. Commission Internationale de l'Éclairage. Standard 17.180.20 (ISO 11664-1:2007): colours and measurement of light. Geneva, 2007. 
DAMODARAN, S.; PARKIN, K.L.; FENNEMA, O.R. (Ed.). Fennema's food chemistry. Boca Raton: CRC Press, 2007. DOI: https://doi.org/10.1201/9781420020526.

DIÉGUEZ, P.M; BERIAIN, M.J.; INSAUSTI, K.; ARRIZUBIETA, M.A. Thermal analysis of meat emulsion cooking process by computer simulation and experimental measurement. International Journal of Food Engineering, v.6, p.1-21, 2010. DOI: https://doi.org/10.2202/1556-3758.1391.

FURLAN, E.F.; OETTERER, M. Hidrolisado protéico de pescado. Revista de Ciência \& Tecnologia, v.10, p.79-89, 2002.

GONÇALVES, A.A. (Ed.). Tecnologia do pescado: ciência, tecnologia, inovação e legislação. São Paulo: Atheneu, 2011. 608p.

HELRICH, K. (Ed.). Official Methods of Analysis of the Association of Official Analytical Chemists. $15^{\text {th }}$ ed. Arlington: AOAC, 1990. Official Methods 923.03, 925.45b, 960.52.

HUSS, H.H. Assurance of seafood quality. Rome: FAO, 1994. (FAO Fisheries Technical Paper, n.334).

ISO. International Organization Standardization. ISO 5509:2000: Animal and vegetable fats and oils: preparation of methyl esters of fatty acids. Geneva, 2000. DOI: https://doi.org/10.3403/02020190.

ISO. International Organization Standardization. ISO 68881: Microbiology of food and animal feeding stuffs: horizontal method for the enumeration of coagulase-positive staphylococci (Staphylococcus aureus and other species): part 1: technique using Baird-Parker agar medium. Genève, 1999.

KONG, J.; YU, S. Fourier transform infrared spectroscopic analysis of protein secondary structures. Acta Biochimica et Biophysica Sinica, v.39, p.549-559, 2007. DOI: https://doi.org/10.1111/j.1745-7270.2007.00320.x.

KRISTINSSON, H.G.; RASCO, B.A. Fish protein hydrolysates: production, biochemical, and functional properties. Critical Reviews in Food Science and Nutrition, v.40, p.43-81, 2000. DOI: https://doi.org/10.1080/10408690091189266.

LATIMER JR., G.W. (Ed.). Official Methods of Analysis of AOAC International. 21 ${ }^{\text {th }}$ ed. Arlington: AOAC, 2019. Microbiological Methods. Official Methods 991.14, 998.08, 2003.11, 2016.01.

NAVARRO, R.D.; NAVARRO, F.K.S.P.; RIBEIRO FILHO, O.P.; FERREIRA, W.M.; PEREIRA, M.M.; SEIXAS FILHO, J.T. Quality of polyunsaturated fatty acids in Nile tilapias (Oreochromis niloticus) fed with vitamin E supplementation. Food Chemistry, v.134, p.215-218, 2012. DOI: https://doi.org/10.1016/j.foodchem.2012.02.097.

OECD-FAO Agricultural Outlook 2018-2027. Paris: OECD; Rome: FAO, 2018. DOI: https://doi.org/10.1787/50d923a2-ko.

PEIXE BR. Associação Brasileira da Piscicultura. Anuário Peixe BR da piscicultura 2018. São Paulo, 2018. Available at: $<$ https:// www.peixebr.com.br/Anuario2018/AnuarioPeixeBR2018.pdf>. Accessed on: Nov. 92020.
PEIXE BR. Associação Brasileira da Piscicultura. Anuário Peixe BR da piscicultura 2020. São Paulo, 2020. Available at: $<$ https:// www.peixebr.com.br/Anuario2020/AnuarioPeixeBR2020.pdf $>$. Accessed on: Nov. 92020.

PLANO de Desenvolvimento da Aquicultura Brasileira 2015/2020. Brasília: Ministério da Pesca e Aquicultura, 2015.

RAHMAN, M.S. $\mathrm{pH}$ in food preservation. In: RAHMAN, M.S. (Ed.). Handbook of food preservation. $2^{\text {nd }}$ ed. Boca Raton: CRC Press, 2007. p.287-298. DOI: https://doi.org/10.1201/9781420017373.ch12.

RAHMAN, M.S.; LABUZA, T.P. Water activity and food preservation. In: RAHMAN, M.S. (Ed.). Handbook of food preservation. $2^{\text {nd }}$ ed. Boca Raton: CRC Press, 2007. p.447-476. DOI: https://doi.org/10.1201/9781420017373.ch20.

RASOARAHONA, J.R.E.; BARNATHAN, G.; BIANCHINI, J.P.; GAYDOU, E.M. Influence of season on the lipid content and fatty acid profiles of three tilapia species (Oreochromis niloticus, $O$. macrochir and Tilapia rendalli) from Madagascar. Food Chemistry, v.91, p.683-694, 2005. DOI: https://doi.org/10.1016/j. foodchem.2004.07.001.

ROBERT,M.;ZATYLNY-GAUDIN,C.;FOURNIER, V.; CORRE, E.; LE CORGUILLÉ, G.; BERNAY, B.; HENRY, J. Molecular characterization of peptide fractions of a tilapia (Oreochromis niloticus) by-product hydrolysate and in vitro evaluation of antibacterial activity. Process Biochemistry, v.50, p.487-492, 2015. DOI: https://doi.org/10.1016/j.procbio.2014.12.022.

ROSLAN, J.; YUNOS, K.F.M.; ABDULLAH, N.; KAMAL, S.M.M. Characterization of fish protein hydrolysate from tilapia (Oreochromis niloticus) by-Product. Agriculture and Agricultural Science Procedia, v.2, p.312-319, 2014.

SILVA-BUZANELLO, R.A. da; SCHUCH, A.F.; NOGUES, D.R.N.; MELO, P.F. de; GASPARIN, A.W.; TORQUATO, A.S.; CANAN, C.; SOARES, A.L. Physicochemical and biochemical parameters of chicken breast meat influenced by stunning methods. Poultry Science, v.97, p.3786-3792, 2018. DOI: https://doi.org/10.3382/ps/pey281.

SILVA, J.F.X.; RIBEIRO, K.; SILVA, J.F.; CAHÚ, T.B.; BEZERRA, R.S. Utilization of tilapia processing waste for the production of fish protein hydrolysate. Animal Feed Science and Technology, v.196, p.96-106, 2014. DOI: https://doi.org/10.1016/j. anifeedsci.2014.06.010.

SOW, L.C.; YANG, H. Effects of salt and sugar addition on the physicochemical properties and nanostructure of fish gelatin. Food Hydrocolloids, v.45, p.72-82, 2015.

WALSH, G. Proteins: Biochemistry and biotechnology. $2^{\text {nd }}$ ed. Hoboken: J. Wiley \& Sons, 2014.

WHITE, J.A.; HART, R.J.; FRY, J.C. An evaluation of the Waters Pico-Tag system for the amino-acid analysis of food materials. The Journal of Automatic Chemistry, v.8, p.170-177, 1986. DOI: https://doi.org/10.1155/S1463924686000330. 